\title{
Assessment of Mothers Level of Satisfaction with Antenatal Care Services Provided at Alganesh Health Center Shire, North West Tigray, Ethiopia
}

\author{
Berhane Fseha* \\ Lecturer, Department of public health college of medicine and health science, Ethiopia \\ *Corresponding author: Berhane Fseha, Department of public health college of medicine and health science, Ethiopia
}

\begin{tabular}{ll}
\hline ARTICLE INFO ABSTRACT \\
\hline
\end{tabular}

Received: 蔧 March 01, 2019

Published: 慧 March 19, 2019

Citation: Berhane Fseha. Assessment of Mothers Level of Satisfaction with Antenatal Care Services Provided at Alganesh Health Center Shire, North West Tigray, Ethiopia. Biomed J Sci \& Tech Res 16(1)-2019. BJSTR. MS.ID.002803.

Abbreviations: ANC: Antenatal Care; ETB: Ethiopian Birr; HIV: Human Immune Virus; OPD: Out Patient Department SPSS: Statistical Package for Social Science
Objective: Antenatal care is the care a pregnant woman receives during her pregnancy through a series of consultations with trained health professionals. Countries with low antenatal care coverage are the countries with very high maternal mortality ratio. One of the important problems which are continuously faced these days is the lack of good quality antenatal care and availing mother's satisfaction. The aim of this study is to assess mother's level of satisfaction with the antenatal care services provided by alganesh health center, north west Tigray, Ethioipia. Across-sectional study was conducted from April-May 2017 at Alganesh health center. Systematic random sampling method was conduct in the study. The collected data were cleaned analysed using SPSS version 20 and presented in tables and figures.

Result: The overall satisfaction was $83.9 \%$ with different satisfaction level of the variables. Majority (90.8\%) of them were satisfied by Examination area cleanliness and 89\% were satisfied by Waiting time to see health worker but the pregnant mothers were not satisfied by Waiting area cleanliness and comfort.

Keywords: Level of Satisfaction; Pregnant Mother; Antenatal Care

\section{Introduction}

Antenatal care is the care for a pregnant woman receives during her pregnancy through a series of consultations with trained health care workers such as midwives, nurses, and sometimes a doctor who specializes in pregnancy and birth [1,2]. Now days the challenging issue throughout the health facility relayed to mother's satisfaction is availability of best quality ante natal care service [3]. Mothers level of satisfaction with the antenatal service given in the health facility is medically important and satisfied mothers had high adherence to the treatment given as well as they will be participant in the service and utilize the antenatal care service [4]. Even though it is believed that mothers' satisfaction is crucial to assure qualified antenatal care service available for all pregnant mothers, little is known regarding mothers' level of satisfaction in Ethiopia [5]. Moreover the current study helps as an insight for any investigators interested in similar study and also particularly aid the respective situation to prepare strategies in providing health system for the assurance of mother's satisfaction. So, the aim of this study is to assess the level of satisfaction of pregnant mothers on antenatal care service and used the finding as base line information for other researchers.

\section{Methods and Materials}

\section{Study Area and Period}

The study was conducted at algaynesh health center shire from April to May 2017. The health center is located $1087 \mathrm{Km}$ away from the capital city of Ethiopia, Addis Ababa \& $305 \mathrm{Km}$ northwest of Mekelle which the capital city of Tigray region. The total population of the town is about 74,512, out of which 36511 (49\%) and 38001 (51\%) were male and female respectively. Shire town has one General Hospital and two health center. Algaynesh health center is one of the health center in shire town and has out 
Patient department (OPD), maternal and child health unite, HIV counseling and testing room pharmacy and laboratory. The health center has 3 HOs, 2 Bsc Nurses, 13diploma nurses, 2 Laboratory technologist, 1 pharmasist and 1 druggist. The health center gives various antenatal care services.

\section{Study Design}

Facility based cross-sectional study was conducted

Source of population: All Mothers attending antenatal care service follow up at Algaynesh health center.

Study population: Study population was all Mothers attending antenatal care service follow up at Algaynesh health center during study period.

\section{Inclusion and Exclusion Criteria}

Inclusion Criteria: all pregnant mothers who were voluntary to participate in the study and their age were $\geq 18$ years.

Exclusion Criteria: severely ill mothers during the data collection period, deaf and less than 18-year mothers were excluded from the study.

\section{Sample Size Determination}

The sample size was calculated using a single population proportion formula assuming, previous prevalence from Sudan; which is $22 \%$ of pregnant women satisfied about the service given at antenatal service [13]. With 5\% margin of error (d) and confidence level of $95 \%(z \alpha / 2=1.96)$. Hence, Sample size is determined by using the following formula

$$
n=\frac{(Z \alpha / 2)^{2} P(1-P)}{d^{2}}
$$

Where

$\mathrm{P}=$ estimate of satisfaction rate for population that is $22 \%$

$$
\mathrm{n}=\text { sample size }
$$

$\mathrm{d}=$ the sampling error tolerated for the $\mathrm{p}$ value $=5 \%$

$$
n=\frac{(1.96)^{2} \times 0.22(1-0.22)}{(0.05)^{2}}=263
$$

Adding the non-response rate $10 \%$ the final sample size were 289 pregnant mothers.

\section{Sampling Procedure}

Systematic random sampling method was applied in the study. The total pregnant mothers registered in the log book in the last one month were 600 client and we divide to our sample size (600/289) gives two. We use lottery method to select the starting mother from the first five clients. every other mother attending antenatal care service follow up during data collection period was included in the study.

\section{Data Collection Tools}

Data was collected by face-to-face interview using a structured and pre-tested questionnaire. The data collectors were regularly supervising by the principal investigators for proper data collection. Three $4^{\text {th }}$ year midwifery's students were recruited as data collectors.

\section{Data Quality Control}

Questionnaire were prepared in English version and translated to the local language Tigrigna. It was pre tested in the nearby health facility which is not selected in the study. Intensive training of three days was given to the data collectors and there was tight supervision by the principal investigator. Additional adjustment was made based on the results of the pre- test. Data were checked for completeness and consistency before commencing analysis.

\section{Variables}

\section{Dependent Variables}

i) Level of satisfaction

\section{Independent Variables}
a) Age
b) Sex
c) Marital status
d) Occupational status
e) Ethnicity
f) Religion
g) Income
h) Educational status

\section{Data Processing and Analysis}

The collected data were entered, cleaned and analysed using SPSS version 20 and presented in tables and figures.

\section{Operational Definition}

Satisfaction: the response on antenatal care services "very satisfied" and "satisfied" was be classified as satisfied and response "very dissatisfied", "dissatisfied" and "neutral" as unsatisfied.

Overall Satisfaction Level: $75 \%$ and above response of the thirteen satisfaction indicator items was categorized under "satisfied" and those who will satisfy less than $75 \%$ of the items will categorize as "unsatisfied" [6].

\section{Ethical Consideration}

The research proposal was approved by the institutional ethical review board of Aksum University Ethiopia, College of health sciences, department of nursing. Written permission of the college was secured and from all respondents written informed consent was secured and approved by ethical review board of Aksum University Ethiopia. participation was purely voluntary, and they can be free to decline or withdraw at any time in the course of the study. So only those willing to participate were included in the study. Personal identification of the respondents was not asked. They were also be assured that the information provided orally be used only for 
research purpose and would therefore be strictly anonymous and Data was entered as confidential, anonymous, aggregate analysis and reporting system was put secured.

\section{Results}

\section{Socio-Demographic Characteristics of the Respondent}

From the total study participants, a total of 284 mothers were participated in the study with a total response rate of $98.2 \%$. From the total study participants 38\% were $20-24$ years age group, $81.3 \%$ were Tigray in ethnicity, $87 \%$ were married in their marital status, $36 \%$ attend secondary education and more than half (55.3\%) were house wife in occupation (Table 1).

Table 1: Socio demo graphic characteristics of the study participants.

\begin{tabular}{|c|c|c|}
\hline \multicolumn{3}{|c|}{ Socio Demographic Characteristics of the Study Participants } \\
\hline Variable & Frequency & Percentage \\
\hline \multicolumn{3}{|c|}{ Age (yrs.) } \\
\hline $15-19$ & 10 & 3.5 \\
\hline $20-24$ & 108 & 38 \\
\hline $25-29$ & 43 & 15.1 \\
\hline $30-34$ & 74 & 26.1 \\
\hline $35-39$ & 32 & 11.3 \\
\hline$>40$ & 12 & 4.2 \\
\hline \multicolumn{3}{|c|}{ Ethnicity } \\
\hline Amhara & 20 & 7 \\
\hline Kunama & 27 & 9.5 \\
\hline Tigray & 231 & 81.3 \\
\hline Other & 1 & 0.3 \\
\hline \multicolumn{3}{|c|}{ Marital Status } \\
\hline Married & 247 & 87 \\
\hline Divorced & 24 & 8.5 \\
\hline Widowed & 08 & 2.8 \\
\hline \multicolumn{3}{|c|}{ Educational status } \\
\hline Can't read \& write & 9 & 3.2 \\
\hline Read \& write & 25 & 8.8 \\
\hline Primary education & 98 & 34.5 \\
\hline Secondary education & 102 & 35.9 \\
\hline College and above & 45 & 15.8 \\
\hline \multicolumn{3}{|c|}{ Income per month } \\
\hline$<1500$ ЕТВ & 188 & 66.2 \\
\hline$\geq 1500$ ЕTВ & 96 & 33.8 \\
\hline \multicolumn{3}{|c|}{ Residence } \\
\hline Rural & 86 & 30.3 \\
\hline Urban & 198 & 69.7 \\
\hline \multicolumn{3}{|l|}{ Religion } \\
\hline Orthodox & 176 & 61.9 \\
\hline Protestant & 5 & 1.8 \\
\hline $\begin{array}{l}\text { Muslim } \\
\text { Other }\end{array}$ & $\begin{array}{c}94 \\
4\end{array}$ & $\begin{array}{c}33.1 \\
1.4\end{array}$ \\
\hline
\end{tabular}

\section{Obstetric Characteristics of the Study Participants}

Majority $(82.7 \%)$ of the study participants had planned pregnancy and more than one third were multipara (Table 2).

Table 2: Obstetric Characteristics of the Study Participants.

\begin{tabular}{|c|c|c|}
\hline \multicolumn{3}{|c|}{ Obstetric Characteristics of the Study Participants } \\
\hline Variable & Frequency & Percentage \\
\hline \multicolumn{3}{|c|}{ Type of pregnancy } \\
\hline Unplanned & 49 & 17.3 \\
\hline Planned & 235 & 82.7 \\
\hline \multicolumn{3}{|l|}{ Parity } \\
\hline Nulliparous & 99 & 34.8 \\
\hline Multipara & 104 & 36.6 \\
\hline Grand multipara & 81 & 28.6 \\
\hline \multicolumn{3}{|l|}{ History of abortion } \\
\hline No & 261 & 91.9 \\
\hline Yes & 23 & 8.1 \\
\hline \multicolumn{3}{|l|}{ History of still birth } \\
\hline No & 12 & 4.2 \\
\hline Yes & 272 & 95.8 \\
\hline \multicolumn{3}{|l|}{ History ANC } \\
\hline No & 7 & 2.5 \\
\hline Yes & 277 & 97.5 \\
\hline \multicolumn{3}{|l|}{ Current visit } \\
\hline First & 59 & 20.7 \\
\hline Second & 73 & 25.7 \\
\hline Third & $\begin{array}{l}81 \\
71\end{array}$ & $\begin{array}{c}28.6 \\
25\end{array}$ \\
\hline
\end{tabular}

\section{Level of Client Satisfaction}

Table 3: level of the pregnant mother satisfaction.

\begin{tabular}{|c|c|c|c|c|c|}
\hline \multicolumn{6}{|c|}{ level of the Pregnant Mother Satisfaction } \\
\hline \multirow[t]{2}{*}{ S. no } & \multirow[t]{2}{*}{ Variable } & \multicolumn{2}{|c|}{ Satisfied } & \multicolumn{2}{|c|}{$\begin{array}{c}\text { Not } \\
\text { satisfied }\end{array}$} \\
\hline & & \multicolumn{2}{|c|}{ N \% } & \multicolumn{2}{|c|}{ N \% } \\
\hline 1 & Examination area cleanliness & 258 & 90.8 & 26 & 9.2 \\
\hline 2 & Waiting time to see health worker & 253 & 89 & 31 & 11 \\
\hline 3 & Courtesy and respect & 222 & 78.1 & 62 & 21.9 \\
\hline 4 & Information and education service & 203 & 71.5 & 81 & 28.5 \\
\hline 5 & Overall cleanliness of the facility & 221 & 77.8 & 63 & 22.9 \\
\hline 6 & Completeness of information & 219 & 77 & 65 & 23 \\
\hline 7 & Access and cleanliness of toilet & 233 & 82 & 51 & 18 \\
\hline 8 & $\begin{array}{l}\text { Confidentiality and trust in } \\
\text { providers }\end{array}$ & 258 & 90.8 & 26 & 9.2 \\
\hline 9 & Availability of drugs and supplies & 266 & 93.6 & 18 & 6.4 \\
\hline 10 & $\begin{array}{l}\text { Waiting area cleanliness and } \\
\text { comfort }\end{array}$ & 193 & 68 & 91 & 32 \\
\hline 11 & Cost paid to service & 284 & 100 & 0 & 0 \\
\hline 12 & Health facility distance & 273 & 96 & 11 & 4 \\
\hline 13 & $\begin{array}{l}\text { Level of privacy during ANC } \\
\text { service }\end{array}$ & 218 & 76.7 & 66 & 23.3 \\
\hline & Overall satisfaction & & & $9 \%$ & \\
\hline
\end{tabular}


The overall satisfaction was $83.9 \%$ with different satisfaction level of the variables. Majority (90.8\%) of them were satisfied by Examination area cleanliness and $89 \%$ were satisfied by Waiting time to see health worker but the pregnant mothers were not satisfied by Waiting area cleanliness and comfort (Table 3). The final result of this study showed that $83.9 \%$ of the pregnant women were satisfied with the service that they had received, divided into $36.4 \%$ very highly satisfied $57.5 \%$ good satisfaction, while the nonsatisfied women represent $16.1 \%$.

\section{Discussion}

In the current study the key findings are the total mother's level of satisfaction with the ante natal care service given in the hospital was $83.9 \%$. Furthermore, the satisfaction degree of mothers was different measured by separate parameters like Examination area cleanliness, Waiting time to see health worker, the service that they had received, and the provision of adequate information. The total mothers satisfaction in this study was $83.9 \%$ and this result was consistent with the finding of the study conducted in different parts of the glob like in Addis Ababa, Ethiopia (89.2\%), Sweden (82\%) and Thailand(84.5), But the result of the current finding related to the level of satisfaction was higher than the result of study in high Nigeria (56.7\%) and study in Khartoum Sudan (39\%) [6-9]. This variation could be due to the perception of satisfaction of the mothers the study population in the different study area; because satisfaction is measured by structured questionnaire. In addition, the difference could be due to the new strategy implementing in Ethiopia about to increase the satisfaction of the client in the health facility by creating companionate respectful and caring professional including the antenatal care.

More than one third $36.4 \%$ of the study population were very highly satisfied and $57.5 \%$ of them were had good satisfaction, while the non-satisfied mother was $16.1 \%$. consistent result was revealed at Basra, Iraq showed that mothers' degree of satisfaction was reported that the satisfaction of pregnant women with the overall service that they had received was $98.2 \%$, separated in to $41.3 \%$ of the mother were very highly satisfied, and more than half $56.9 \%$ of them were fairly satisfied [10]. Mothers were satisfied with majority of the parameter used to measure level of satisfaction like examination area cleanliness, Waiting time to see health worker, Courtesy and respect, Overall cleanliness of the facility, Completeness of information, Access and cleanliness of toilet, Confidentiality and trust in providers, Availability of drugs and supplies, Cost paid to service, Health facility distance, Level of privacy during ANC service and mothers that were not satisfied by Information and education service, Waiting area cleanliness and comfort parameters. Comments given by the mothers were to enhance the information delivering, to make clean the waiting area and should be comfortable for pregnant mothers. This finding was consistent with different studies conducted in Ethiopia, Bangladesh and Oman [11-13].

\section{Limitation of the Study}

This study had some limitations:

i. It is cross-sectional, and so the temporal relationship between satisfaction and different background variable cannot be done.

ii. The authors did not measure expectations as satisfaction.

\section{Declarations}

\section{Ethics Approval and Consent to Participate}

The research proposal was approved by the institutional ethical review board of Aksum University Ethiopia, College of health sciences, department of nursing. Written permission of the college was secured and from all respondents written informed consent was secured and approved by ethical review board of Aksum University Ethiopia. participation was purely voluntary, and they can be free to decline or withdraw at any time in the course of the study. So only those willing to participate were included in the study. Personal identification of the respondents was not asked. They were also be assured that the information provided orally be used only for research purpose and would therefore be strictly anonymous and Data was entered as confidential, anonymous, aggregate analysis and reporting system was put secured.

\section{Consent for Publication}

Not applicable

\section{Availability of Data and Material}

a) All data generated or analysed during this study are included in this published article and its supplementary information files.

b) The datasets used and/or analysed during the current study are available from the corresponding author on reasonable request.

\section{Authors Contribution}

$\mathrm{BF}$ participated in the preparation of the proposal, design of the study, data analysis and present the data, preparing daft of the manuscript and critically reviewing. Similarly, SG participated in the design of the study, data analysis and presentation, reviewing of the manuscript. Both authors read, accepted and approved the final manuscript

\section{Acknowledgement}

we would like to thank health professional working in the health center for their cooperation in supplying me with necessary information and document during data collection. And also, we acknowledge all study participants.

\section{References}

1. Bustreo F, Say L, Koblinsky M, Pullum TW, Temmerman M, et al. (2013) Ending preventable maternal deaths: the time is now. Lancet Glob Heal 1(4): 176-177. 
2. (2010) Maternal Mortality Fact Sheet. World Health Organization.

3. Rahman MM, Ngadan DP, Arif MT (2016) Factors affecting satisfaction on antenatal care services in Sarawak, Malaysia: evidence from a cross sectional study. Springerplus 5(1): 725.

4. Pascoe GC (1983) Patient satisfaction in primary health care: a literature review and analysis. Eval Prog Plan 6(3-4): 185-210.

5. Chemir, Alemseged F, Workneh (2014) Satisfaction with focused antenatal care service and associated factors among pregnant women attending focused antenatal care at health centers in Jimma town, Jimma zone, South West Ethiopia; a facility based cross-sectional study triangulated with qualitative study. BMC Research Notes 7: 164.

6. Tesfaye DT, Mekonnen AH, Negesa BL (2017) Maternal Antenatal Care Service Satisfaction and Factors Associated with Rural Health Centers, Bursa District, Sidama Zone, Southern Ethiopia: A Cross-sectional Study. J Women's Health Care 6: 363.

7. Sinshaw W (2009) Assessment of Quality of Antenatal Care in Addis Ababa Health Centers. Addis Ababa: Addis Ababa University, Ethiopia.

\section{ISSN: 2574-1241}

DOI: 10.26717/BJSTR.2019.16.002803

Berhane Fseha. Biomed J Sci \& Tech Res

This work is licensed under Creative

Commons Attribution 4.0 License

Submission Link: https://biomedres.us/submit-manuscript.php
8. Nwaeze IL, Enabor 00, Oluwasola TA, Aimakhu CO (2013) Perception and satisfaction with quality of antenatal care services among pregnant women at the university college hospital, ibadan, Nigeria. Ann Ib Postgrad Med 11(1): 22-28.

9. Hildingsson I, Radestad J (2005) Swedish women's satisfaction with medical and emotional aspects of antenatal care. J Adv Nurs 52(3): 239249.

10. Salam MA, Mahidon M (1998) Factors Influencing Client Satisfaction Towards Antenatal Care Service in the $\mathrm{MCH}$ Hospital. Ratchaburi Province, Thailand.

11. Salman MA (2005) Thesis, Iraqi board for medical specialization.

12. Ghobashi M, Khandekar R (2008) Satisfaction among Expectant Mothers with Antenatal Care Services in the Musandam Region of Oman. Sultan Qaboos Univ Med J 8(3): 325-332.

13. Hasan A (2007) Patient Satisfaction with Maternal and Child Health Services. Dhaka: Mahidol University, Thailand.

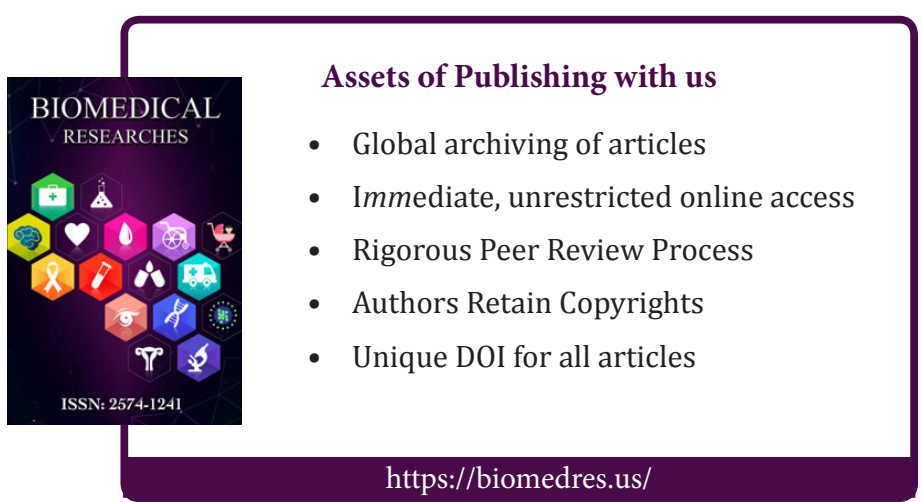

